\title{
Molecular Psychiatry, August 2020: new impact factor, and highlights of recent advances in psychiatry, including an overview of the brain's response to stress during infection with the severe acute respiratory syndrome coronavirus 2 (SARS-CoV-2)
}

\author{
Julio Licinio $\mathbb{( D D}^{1} \cdot$ Ma-Li Wong $\mathbb{D}^{1}$
}

Received: 3 July 2020 / Revised: 10 July 2020 / Accepted: 10 July 2020

(c) The Author(s) 2020. This article is published with open access

We are delighted that the 2019 Impact Factor (IF) figures have recently been released by the Journal Citation Reports ${ }^{\circledast}$ Science Edition (Clarivate Analytics, 2020). As you know, the IF is calculated as total citations in 2019 of all papers published by a journal in $2017+2018$ divided by the total numbers of full articles published in $2017+2018$. I am delighted that the 2019 Impact Factor for Molecular Psychiatry is now 12.384 (an increase from 11.973 in the previous year). What is particularly remarkable is that we have achieved that while simultaneously increasing the number of outstanding work that we publish.

Molecular Psychiatry's 2019 Journal Citation Reports ranking is as follows: 6th of 155 in Psychiatry, 10th of 271 in Neuroscience, and 11th of 297 in Biochemistry \& Molecular Biology. We would like to sincerely thank all of you, authors, readers, and editorial board members, for your support of Molecular Psychiatry over the years, which has been essential for the journal to achieve its high level of continued success.

This year we published four special issues, one on schizophrenia [1-19], one on stress and behavior [20-38], and two on depression, in June [39-55] and July [56-76]. We now go back to our regular publishing schedule, highlighting in this issue incredible progress in several different areas of psychiatry. This editorial will highlight some of that progress.

This exciting issue starts with a guest editorial by Steenblock et al., on the impact of SARS-CoV-2 infection and the neuroendocrine stress axis [77]. We then have two

Julio Licinio

juliolicinio@gmail.com

1 State University of New York, Upstate Medical University, Syracuse, NY 13210, USA interesting Perspectives, one by the Consortium on Vulnerability to Externalizing Disorders and Addictions (cVEDA), in which they examine an accelerated longitudinal cohort of children and adolescents in India [78], and the other by Thapar \& Riglin commenting on the importance of a developmental perspective in Psychiatry, and answering the essential question: what do recent geneticepidemiological findings show? [79] These exciting Perspectives are followed by three important Reviews: by Prieto et al. on post-translational modifications of the Fragile X Mental Retardation Protein in neuronal function and dysfunction; by Rogdaki et al., a meta-analysis of the magnitude and heterogeneity of brain structural abnormalities in 22q11.2 deletion syndrome [80], and by Smigielski et al., a systematic review of empirical human findings on the epigenetic mechanisms in schizophrenia and other psychotic disorders [81].

We have Immediate Communications as a unique manuscript type in Molecular Psychiatry. Those papers are rapidly reviewed, and accepted only if the reviews are particularly favorable. They are then prioritized for publication. We have three Immediate Communications in this issue. Dempster et al. present a 7-T magnetic resonance spectroscopic study of glutathione and glutamate showing early treatment response in first-episode psychosis [82]; Niculescu et al. present intriguing work on blood biomarkers for memory that can be targeted toward early detection of risk for Alzheimer's disease (AD), pharmacogenomics, and repurposed drugs [83], and Polimanti et al. leverage genome-wide data to investigate differences between opioid use versus opioid dependence in 41,176 individuals from the Psychiatric Genomics Consortium [84].

Regular articles in this issue start with the paper that is the topic of our Image Section, in which we highlight striking figures that illustrate important new discoveries. In 
that article, Du et al. show that cocaine-induced ischemia in the prefrontal cortex is associated with escalation of cocaine intake in rodents [85]. In other original research articles, we present key new advances across multiple fields. Kendler et al. show that the risk for drug abuse, alcohol use disorder, and psychosocial dysfunction in offspring from highdensity pedigrees is moderated by personal, family, and community factors [86]. Harrison et al. present a systematic review and meta-analysis of the neuropathology of bipolar disorder [87]. Brikell et al. examine the contribution of common genetic risk variants for attention-deficit/hyperactivity disorder (ADHD) to a general factor of childhood psychopathology. Their results suggest that common genetic risk variants associated with ADHD, and captured by polygenic risk scores (PRS), also influence a general genetic liability towards broad childhood psychopathology in the general population, in addition to a specific association with hyperactivity/impulsivity symptoms [88].

In our beautiful cover article, Sun et al. conducted largescale mapping of cortical alterations in 22q11.2 deletion syndrome demonstrating convergence with idiopathic psychosis and effects of deletion size [89]. They found a robust neuroanatomic signature of 22q11DS, and the first evidence that deletion size impacts brain structure and that psychotic illness in this highly penetrant deletion was associated with similar neuroanatomic abnormalities to idiopathic schizophrenia.

Our original research articles continue with other remarkable papers. Amal et al. provide evidence that mutation in a mouse model of autism leads to changes in the S-nitroso-proteome and affects key proteins involved in vesicle release and synaptic function [90]. In a randomized clinical trial conducted in Japan, Yamasue et al. studied the effects of intranasal oxytocin on the core social symptoms of autism spectrum disorder (ADS) [91]. They did not find highly beneficial clinical outcomes other than on repetitive behavior and gaze fixation on socially relevant regions. There were no significant differences in the prevalence of adverse events between groups. Based on their findings, they cannot recommend continuous intranasal oxytocin treatment alone at the current dose and duration for treatment of the core social symptoms of high-functioning ASD in adult men, although this large-scale trial suggests oxytocin's possibility to treat ASD repetitive behavior. Bis et al. used whole-exome sequencing to identify novel rare and common AD-associated variants involved in immune response and transcriptional regulation [92]. In our last original article, Temido-Ferreira shows that age-related shift in long-term depression (LTD), is dependent on neuronal adenosine A2A receptors (A2AR) interplay with metabotropic glutamate receptor type 5 (mGluR5) and N-Methyl-daspartate (NMDA) receptors [93]. The authors suggest that this A2AR/mGluR5/NMDAR interaction might prove a suitable alternative for regulating aberrant mGluR5/ NMDAR signaling in AD without disrupting their constitutive activity.

These superb articles across a variety of field of great importance to the broad field of molecular psychiatry demonstrate that Molecular Psychiatry, with a new IF of 12.384 , is now the premier journal in our field that integrates clinical psychiatry with molecular neurobiology, genetics/genomics, imaging, and other state-of-the-art approaches that unravel the pathways and mechanisms underlying psychiatric disorders.

Open Access This article is licensed under a Creative Commons Attribution 4.0 International License, which permits use, sharing, adaptation, distribution and reproduction in any medium or format, as long as you give appropriate credit to the original author(s) and the source, provide a link to the Creative Commons license, and indicate if changes were made. The images or other third party material in this article are included in the article's Creative Commons license, unless indicated otherwise in a credit line to the material. If material is not included in the article's Creative Commons license and your intended use is not permitted by statutory regulation or exceeds the permitted use, you will need to obtain permission directly from the copyright holder. To view a copy of this license, visit http://creativecommons. org/licenses/by/4.0/.

\section{References}

1. Koshiyama D, Fukunaga M, Okada N, Morita K, Nemoto K, Usui $\mathrm{K}$, et al. White matter microstructural alterations across four major psychiatric disorders: mega-analysis study in 2937 individuals. Mol Psychiatry. 2020;25:883-95.

2. Licinio J. Advances in schizophrenia research: first special issue, 2020. Mol Psychiatry. 2020;25:699-700.

3. Passos IC, Mwangi B. Machine learning-guided intervention trials to predict treatment response at an individual patient level: an important second step following randomized clinical trials. Mol Psychiatry. 2020;25:701-2.

4. Reay WR, Cairns MJ. The role of the retinoids in schizophrenia: genomic and clinical perspectives. Mol Psychiatry. 2020;25:706-18.

5. Reay WR, Atkins JR, Quide Y, Carr VJ, Green MJ, Cairns MJ. Polygenic disruption of retinoid signalling in schizophrenia and a severe cognitive deficit subtype. Mol Psychiatry. 2020;25:719-31.

6. Petrelli F, Dallerac G, Pucci L, Cali C, Zehnder T, Sultan S, et al. Dysfunction of homeostatic control of dopamine by astrocytes in the developing prefrontal cortex leads to cognitive impairments. Mol Psychiatry. 2020;25:732-49.

7. Wang HY, MacDonald ML, Borgmann-Winter KE, Banerjee A, Sleiman P, Tom A, et al. mGluR5 hypofunction is integral to glutamatergic dysregulation in schizophrenia. Mol Psychiatry. 2020;25:750-60.

8. Cai HQ, Catts VS, Webster MJ, Galletly C, Liu D, O’Donnell M, et al. Increased macrophages and changed brain endothelial cell gene expression in the frontal cortex of people with schizophrenia displaying inflammation. Mol Psychiatry. 2020;25:761-75.

9. Scott MR, Meador-Woodruff JH. Intracellular compartmentspecific proteasome dysfunction in postmortem cortex in schizophrenia subjects. Mol Psychiatry. 2020;25:776-90.

10. Radulescu E, Jaffe AE, Straub RE, Chen Q, Shin JH, Hyde TM, et al. Identification and prioritization of gene sets associated with 
schizophrenia risk by co-expression network analysis in human brain. Mol Psychiatry. 2020;25:791-804.

11. Bergman O, Karry R, Milhem J, Ben-Shachar D. NDUFV2 pseudogene (NDUFV2P1) contributes to mitochondrial complex I deficits in schizophrenia. Mol Psychiatry. 2020;25:805-20.

12. Chaumette B, Ferrafiat V, Ambalavanan A, Goldenberg A, Dionne-Laporte A, Spiegelman D, et al. Missense variants in ATP1A3 and FXYD gene family are associated with childhoodonset schizophrenia. Mol Psychiatry. 2020;25:821-30.

13. Ma L, Semick SA, Chen Q, Li C, Tao R, Price AJ, et al. Schizophrenia risk variants influence multiple classes of transcripts of sorting nexin 19 (SNX19). Mol Psychiatry. 2020;25:831-43.

14. Smeland OB, Bahrami S, Frei O, Shadrin A, O’Connell K, Savage $\mathrm{J}$, et al. Genome-wide analysis reveals extensive genetic overlap between schizophrenia, bipolar disorder, and intelligence. Mol Psychiatry. 2020;25:844-53.

15. Warland A, Kendall KM, Rees E, Kirov G, Caseras X. Schizophrenia-associated genomic copy number variants and subcortical brain volumes in the UK Biobank. Mol Psychiatry. 2020;25:854-62.

16. Doucet GE, Moser DA, Luber MJ, Leibu E, Frangou S. Baseline brain structural and functional predictors of clinical outcome in the early course of schizophrenia. Mol Psychiatry. 2020;25:863-72.

17. Kumar J, Liddle EB, Fernandes CC, Palaniyappan L, Hall EL, Robson SE, et al. Glutathione and glutamate in schizophrenia: a 7T MRS study. Mol Psychiatry. 2020;25:873-82.

18. Hadar R, Winter R, Edemann-Callesen H, Wieske F, Habelt B, Khadka N, et al. Prevention of schizophrenia deficits via noninvasive adolescent frontal cortex stimulation in rats. Mol Psychiatry. 2020;25:896-905.

19. Cao B, Cho RY, Chen D, Xiu M, Wang L, Soares JC, et al. Treatment response prediction and individualized identification of first-episode drug-naive schizophrenia using brain functional connectivity. Mol Psychiatry. 2020;25:906-13.

20. Licinio J. Advances in research on stress and behavior: special issue, 2020. Mol Psychiatry. 2020;25:916-7.

21. Martinez ME, Duarte CW, Stohn JP, Karaczyn A, Wu Z, DeMambro VE, et al. Thyroid hormone overexposure decreases DNA methylation in germ cells of newborn male mice. Mol Psychiatry. 2020;25:915.

22. Martinez ME, Duarte CW, Stohn JP, Karaczyn A, Wu Z, DeMambro VE, et al. Thyroid hormone influences brain gene expression programs and behaviors in later generations by altering germ line epigenetic information. Mol Psychiatry. 2020;25: 939-50.

23. Le-Niculescu H, Roseberry K, Levey DF, Rogers J, Kosary K, Prabha S, et al. Towards precision medicine for stress disorders: diagnostic biomarkers and targeted drugs. Mol Psychiatry. 2020;25:918-38.

24. Torres-Berrio A, Nouel D, Cuesta S, Parise EM, Restrepo-Lozano JM, Larochelle P, et al. MiR-218: a molecular switch and potential biomarker of susceptibility to stress. Mol Psychiatry. 2020;25:951-64.

25. Sillivan SE, Jamieson S, de Nijs L, Jones M, Snijders C, Klengel $\mathrm{T}$, et al. Correction: MicroRNA regulation of persistent stressenhanced memory. Mol Psychiatry. 2020;25:1154.

26. Sillivan SE, Jamieson S, de Nijs L, Jones M, Snijders C, Klengel $\mathrm{T}$, et al. MicroRNA regulation of persistent stress-enhanced memory. Mol Psychiatry. 2020;25:965-76.

27. Shi MM, Fan KM, Qiao YN, Xu JH, Qiu LJ, Li X, et al. Hippocampal micro-opioid receptors on GABAergic neurons mediate stress-induced impairment of memory retrieval. Mol Psychiatry. 2020;25:977-92.

28. Mayo LM, Asratian A, Linde J, Holm L, Natt D, Augier G, et al. Protective effects of elevated anandamide on stress and fear- related behaviors: translational evidence from humans and mice. Mol Psychiatry. 2020;25:993-1005.

29. Qu N, He Y, Wang C, Xu P, Yang Y, Cai X, et al. A POMCoriginated circuit regulates stress-induced hypophagia, depression, and anhedonia. Mol Psychiatry. 2020;25:1006-21.

30. Fox ME, Chandra R, Menken MS, Larkin EJ, Nam H, Engeln M, et al. Dendritic remodeling of D1 neurons by RhoA/Rho-kinase mediates depression-like behavior. Mol Psychiatry. 2020;25: 1022-34.

31. Jin J, Bhatti DL, Lee KW, Medrihan L, Cheng J, Wei J, et al. Ahnak scaffolds p11/Anxa2 complex and L-type voltage-gated calcium channel and modulates depressive behavior. Mol Psychiatry. 2020;25:1035-49.

32. Ben-Yehuda H, Matcovitch-Natan O, Kertser A, Spinrad A, Prinz M, Amit I, et al. Maternal Type-I interferon signaling adversely affects the microglia and the behavior of the offspring accompanied by increased sensitivity to stress. Mol Psychiatry. 2020;25:1050-67.

33. Pearson-Leary J, Zhao C, Bittinger K, Eacret D, Luz S, Vigderman AS, et al. The gut microbiome regulates the increases in depressive-type behaviors and in inflammatory processes in the ventral hippocampus of stress vulnerable rats. Mol Psychiatry. 2020;25:1068-79.

34. Walker WH II, Borniger JC, Gaudier-Diaz MM, Hecmarie Melendez-Fernandez O, Pascoe JL, Courtney DeVries A, et al. Acute exposure to low-level light at night is sufficient to induce neurological changes and depressive-like behavior. Mol Psychiatry. 2020;25:1080-93.

35. Lei Y, Wang J, Wang D, Li C, Liu B, Fang X, et al. SIRT1 in forebrain excitatory neurons produces sexually dimorphic effects on depression-related behaviors and modulates neuronal excitability and synaptic transmission in the medial prefrontal cortex. Mol Psychiatry. 2020;25:1094-111.

36. Sargin D, Chottekalapanda RU, Perit KE, Yao V, Chu D, Sparks DW, et al. Mapping the physiological and molecular markers of stress and SSRI antidepressant treatment in S100a10 corticostriatal neurons. Mol Psychiatry. 2020;25:1112-29.

37. Iob E, Kirschbaum C, Steptoe A. Persistent depressive symptoms, HPA-axis hyperactivity, and inflammation: the role of cognitiveaffective and somatic symptoms. Mol Psychiatry. 2020;25: $1130-40$

38. Cabeza de Baca T, Prather AA, Lin J, Sternfeld B, Adler N, Epel ES, et al. Chronic psychosocial and financial burden accelerates 5year telomere shortening: findings from the Coronary Artery Risk Development in Young Adults Study. Mol Psychiatry. 2020;25: 1141-53.

39. Zhang Y, Du L, Bai Y, Han B, He C, Gong L, et al. Colocalization of circDYM with miR-9 in microglia. Mol Psychiatry. 2020;25:1155.

40. Licinio J, Wong ML. Advances in depression research: special issue, 2020, with three research articles by Paul Greengard. Mol Psychiatry. 2020;25:1156-8.

41. Teissier A, Le Magueresse C, Olusakin J, Andrade da Costa BLS, De Stasi AM, Bacci A, et al. Early-life stress impairs postnatal oligodendrogenesis and adult emotional behaviour through activity-dependent mechanisms. Mol Psychiatry. 2020;25: 1159-74.

42. Zhang Y, Du L, Bai Y, Han B, He C, Gong L, et al. CircDYM ameliorates depressive-like behavior by targeting miR-9 to regulate microglial activation via HSP90 ubiquitination. Mol Psychiatry. 2020;25:1175-90.

43. Sagi Y, Medrihan L, George K, Barney M, McCabe KA, Greengard P. Emergence of 5-HT5A signaling in parvalbumin neurons mediates delayed antidepressant action. Mol Psychiatry. 2020;25:1191-201. 
44. Kin K, Yasuhara T, Kameda M, Tomita Y, Umakoshi M, Kuwahara K, et al. Cell encapsulation enhances antidepressant effect of the mesenchymal stem cells and counteracts depressivelike behavior of treatment-resistant depressed rats. Mol Psychiatry. 2020;25:1202-14.

45. Oh SJ, Cheng J, Jang JH, Arace J, Jeong M, Shin $\mathrm{CH}$, et al. Hippocampal mossy cell involvement in behavioral and neurogenic responses to chronic antidepressant treatment. Mol Psychiatry. 2020;25:1215-28.

46. Shuto T, Kuroiwa M, Sotogaku N, Kawahara Y, Oh YS, Jang JH, et al. Obligatory roles of dopamine D1 receptors in the dentate gyrus in antidepressant actions of a selective serotonin reuptake inhibitor, fluoxetine. Mol Psychiatry. 2020;25:1229-44.

47. Orrico-Sanchez A, Chausset-Boissarie L, Alves de Sousa R, Coutens B, Rezai Amin S, Vialou V, et al. Antidepressant efficacy of a selective organic cation transporter blocker in a mouse model of depression. Mol Psychiatry. 2020;25:1245-59.

48. Han Y, Sun CY, Meng SQ, Tabarak S, Yuan K, Cao L, et al. Systemic immunization with altered myelin basic protein peptide produces sustained antidepressant-like effects. Mol Psychiatry. 2020;25:1260-74.

49. Wittenberg GM, Stylianou A, Zhang Y, Sun Y, Gupta A, Jagannatha PS, et al. Effects of immunomodulatory drugs on depressive symptoms: a mega-analysis of randomized, placebocontrolled clinical trials in inflammatory disorders. Mol Psychiatry. 2020;25:1275-85.

50. Beydoun MA, Obhi HK, Weiss J, Canas JA, Beydoun HA, Evans MK, et al. Systemic inflammation is associated with depressive symptoms differentially by sex and race: a longitudinal study of urban adults. Mol Psychiatry. 2020;25:1286-300.

51. Felger JC, Haroon E, Patel TA, Goldsmith DR, Wommack EC, Woolwine BJ, et al. What does plasma CRP tell us about peripheral and central inflammation in depression? Mol Psychiatry. 2020;25:1301-11.

52. Wei YB, McCarthy M, Ren H, Carrillo-Roa T, Shekhtman T, DeModena A, et al. A functional variant in the serotonin receptor 7 gene (HTR7), rs7905446, is associated with good response to SSRIs in bipolar and unipolar depression. Mol Psychiatry. 2020;25:1312-22.

53. Tan A, Costi S, Morris LS, Van Dam NT, Kautz M, Whitton AE, et al. Effects of the KCNQ channel opener ezogabine on functional connectivity of the ventral striatum and clinical symptoms in patients with major depressive disorder. Mol Psychiatry. 2020;25:1323-33.

54. Clark SL, Hattab MW, Chan RF, Shabalin AA, Han LKM, Zhao $\mathrm{M}$, et al. A methylation study of long-term depression risk. Mol Psychiatry. 2020;25:1334-43.

55. Aberg KA, Dean B, Shabalin AA, Chan RF, Han LKM, Zhao M, et al. Methylome-wide association findings for major depressive disorder overlap in blood and brain and replicate in independent brain samples. Mol Psychiatry. 2020;25:1344-54.

56. Halikere A, Popova D, Scarnati MS, Hamod A, Swerdel MR, Moore JC, et al. Modelling the single most common SNP in OPRM1 (A118G) using human neurons generated from two sets of independently targeted isogenic stem cell lines. Mol Psychiatry. 2020;25:1355.

57. Halikere A, Popova D, Scarnati MS, Hamod A, Swerdel MR, Moore JC, et al. Addiction associated N40D mu-opioid receptor variant modulates synaptic function in human neurons. Mol Psychiatry. 2020;25:1406-19.

58. Licinio J, Wong ML. Advances in depression research: second special issue, 2020, with highlights on biological mechanisms, clinical features, co-morbidity, genetics, imaging, and treatment. Mol Psychiatry. 2020;25:1356-60.

59. Koch SBJ, Morey RA, Roelofs K. The role of the dentate gyrus in stress-related disorders. Mol Psychiatry. 2020;25:1361-3.
60. Chottekalapanda RU, Kalik S, Gresack J, Ayala A, Gao M, Wang $\mathrm{W}$, et al. AP-1 controls the p11-dependent antidepressant response. Mol Psychiatry. 2020;25:1364-81.

61. Schouten M, Bielefeld P, Garcia-Corzo L, Passchier EMJ, Gradari $\mathrm{S}$, Jungenitz $\mathrm{T}$, et al. Circadian glucocorticoid oscillations preserve a population of adult hippocampal neural stem cells in the aging brain. Mol Psychiatry. 2020;25:1382-405.

62. Amare AT, Vaez A, Hsu YH, Direk N, Kamali Z, Howard DM, et al. Bivariate genome-wide association analyses of the broad depression phenotype combined with major depressive disorder, bipolar disorder or schizophrenia reveal eight novel genetic loci for depression. Mol Psychiatry. 2020;25:1420-9.

63. Coleman JRI, Peyrot WJ, Purves KL, Davis KAS, Rayner C, Choi SW, et al. Correction: Genome-wide gene-environment analyses of major depressive disorder and reported lifetime traumatic experiences in UK Biobank. Mol Psychiatry. 2020;25:1430-46.

64. Belvederi Murri M, Amore M, Respino M, Alexopoulos GS. The symptom network structure of depressive symptoms in late-life: Results from a European population study. Mol Psychiatry. 2020;25:1447-56.

65. Simmons WK, Burrows K, Avery JA, Kerr KL, Taylor A, Bodurka J, et al. Appetite changes reveal depression subgroups with distinct endocrine, metabolic, and immune states. Mol Psychiatry. 2020;25:1457-68

66. Mulugeta A, Zhou A, King C, Hypponen E. Association between major depressive disorder and multiple disease outcomes: a phenome-wide Mendelian randomisation study in the UK Biobank. Mol Psychiatry. 2020;25:1469-76.

67. Khandaker GM, Zuber V, Rees JMB, Carvalho L, Mason AM, Foley $\mathrm{CN}$, et al. Shared mechanisms between coronary heart disease and depression: findings from a large UK general population-based cohort. Mol Psychiatry. 2020;25:1477-86.

68. Wang YH, Li JQ, Shi JF, Que JY, Liu JJ, Lappin JM, et al. Depression and anxiety in relation to cancer incidence and mortality: a systematic review and meta-analysis of cohort studies. Mol Psychiatry. 2020;25:1487-99.

69. Cooper CM, Chin Fatt CR, Liu P, Grannemann BD, Carmody T, Almeida JRC, et al. Discovery and replication of cerebral blood flow differences in major depressive disorder. Mol Psychiatry. 2020;25:1500-10.

70. van Velzen LS, Kelly S, Isaev D, Aleman A, Aftanas LI, Bauer J, et al. White matter disturbances in major depressive disorder: a coordinated analysis across 20 international cohorts in the ENIGMA MDD working group. Mol Psychiatry. 2020;25: 1511-25.

71. Greenberg T, Fournier JC, Stiffler R, Chase HW, Almeida JR, Aslam $\mathrm{H}$, et al. Reward related ventral striatal activity and differential response to sertraline versus placebo in depressed individuals. Mol Psychiatry. 2020;25:1526-36.

72. Korgaonkar MS, Goldstein-Piekarski AN, Fornito A, Williams LM. Intrinsic connectomes are a predictive biomarker of remission in major depressive disorder. Mol Psychiatry. 2020;25: 1537-49.

73. Repple J, Mauritz M, Meinert S, de Lange SC, Grotegerd D, Opel $\mathrm{N}$, et al. Severity of current depression and remission status are associated with structural connectome alterations in major depressive disorder. Mol Psychiatry. 2020;25:1550-8.

74. Papakostas GI, Johe K, Hand H, Drouillard A, Russo P, Kay G, et al. A phase 2, double-blind, placebo-controlled study of NSI189 phosphate, a neurogenic compound, among outpatients with major depressive disorder. Mol Psychiatry. 2020;25:1569-79.

75. Fava M, Thase ME, Trivedi MH, Ehrich E, Martin WF, Memisoglu A, et al. Opioid system modulation with buprenorphine/ samidorphan combination for major depressive disorder: two randomized controlled studies. Mol Psychiatry. 2020;25: $1580-91$. 
76. Fava M, Freeman MP, Flynn M, Judge H, Hoeppner BB, Cusin $\mathrm{C}$, et al. Double-blind, placebo-controlled, dose-ranging trial of intravenous ketamine as adjunctive therapy in treatmentresistant depression (TRD). Mol Psychiatry. 2020;25: 1592-603.

77. Steenblock C, Todorov V, Kanczkowski W, Eisenhofer G, Schedl A, Wong ML, et al. Severe acute respiratory syndrome coronavirus 2 (SARS-CoV-2) and the neuroendocrine stress axis. Mol Psychiatry. 2020. https://doi.org/10.1038/s41380020-0758-9.

78. Zhang Y, Vaidya N, Iyengar U, Sharma E, Holla B, Ahuja CK, et al. The Consortium on Vulnerability to Externalizing Disorders and Addictions (c-VEDA): an accelerated longitudinal cohort of children and adolescents in India. Mol Psychiatry. 2020. https:// doi.org/10.1038/s41380-020-0656-1.

79. Thapar A, Riglin L. The importance of a developmental perspective in Psychiatry: what do recent genetic-epidemiological findings show? Mol Psychiatry. 2020. https://doi.org/10.1038/ s41380-020-0648-1.

80. Rogdaki M, Gudbrandsen M, McCutcheon RA, Blackmore CE, Brugger S, Ecker C, et al. Magnitude and heterogeneity of brain structural abnormalities in 22q11.2 deletion syndrome: a metaanalysis. Mol Psychiatry. 2020. https://doi.org/10.1038/s41380019-0638-3.

81. Smigielski L, Jagannath V, Rossler W, Walitza S, Grunblatt E. Epigenetic mechanisms in schizophrenia and other psychotic disorders: a systematic review of empirical human findings. Mol Psychiatry. 2020. https://doi.org/10.1038/s41380-019-0601-3.

82. Dempster K, Jeon P, MacKinley M, Williamson P, Theberge J, Palaniyappan L. Early treatment response in first episode psychosis: a 7-T magnetic resonance spectroscopic study of glutathione and glutamate. Mol Psychiatry. 2020. https://doi.org/10. 1038/s41380-020-0704-x.

83. Niculescu AB, Le-Niculescu H, Roseberry K, Wang S, Hart J, Kaur A, et al. Blood biomarkers for memory: toward early detection of risk for Alzheimer disease, pharmacogenomics, and repurposed drugs. Mol Psychiatry. 2019. https://doi.org/10.1038/ s41380-019-0602-2.

84. Polimanti R, Walters RK, Johnson EC, McClintick JN, Adkins AE, Adkins DE, et al. Leveraging genome-wide data to investigate differences between opioid use vs. opioid dependence in 41,176 individuals from the Psychiatric Genomics Consortium.
Mol Psychiatry. 2020. https://doi.org/10.1038/s41380-0200677-9.

85. Du C, Volkow ND, You J, Park K, Allen CP, Koob GF, et al. Cocaine-induced ischemia in prefrontal cortex is associated with escalation of cocaine intake in rodents. Mol Psychiatry. 2018. https://doi.org/10.1038/s41380-018-0261-8.

86. Kendler KS, Ohlsson H, Bacanu S, Sundquist J, Sundquist K. The risk for drug abuse, alcohol use disorder, and psychosocial dysfunction in offspring from high-density pedigrees: its moderation by personal, family, and community factors. Mol Psychiatry. 2018. https://doi.org/10.1038/s41380-018-0111-8.

87. Harrison PJ, Colbourne L, Harrison CH. The neuropathology of bipolar disorder: systematic review and meta-analysis. Mol Psychiatry. 2018. https://doi.org/10.1038/s41380-018-0213-3.

88. Brikell I, Larsson H, Lu Y, Pettersson E, Chen Q, Kuja-Halkola R, et al. The contribution of common genetic risk variants for ADHD to a general factor of childhood psychopathology. Mol Psychiatry. 2018. https://doi.org/10.1038/s41380-018-0109-2.

89. Sun D, Ching CRK, Lin A, Forsyth JK, Kushan L, Vajdi A, et al. Large-scale mapping of cortical alterations in 22q11.2 deletion syndrome: convergence with idiopathic psychosis and effects of deletion size. Mol Psychiatry. 2018. https://doi.org/10.1038/ s41380-018-0078-5.

90. Amal H, Barak B, Bhat V, Gong G, Joughin BA, Wang X, et al. Shank3 mutation in a mouse model of autism leads to changes in the S-nitroso-proteome and affects key proteins involved in vesicle release and synaptic function. Mol Psychiatry. 2018. https://doi.org/10.1038/s41380-018-0113-6.

91. Yamasue H, Okada T, Munesue T, Kuroda M, Fujioka T, Uno Y, et al. Effect of intranasal oxytocin on the core social symptoms of autism spectrum disorder: a randomized clinical trial. Mol Psychiatry. 2018. https://doi.org/10.1038/s41380-018-0097-2.

92. Bis JC, Jian X, Kunkle BW, Chen Y, Hamilton-Nelson KL, Bush WS, et al. Whole exome sequencing study identifies novel rare and common Alzheimer's-Associated variants involved in immune response and transcriptional regulation. Mol Psychiatry. 2018. https://doi.org/10.1038/s41380-018-0112-7.

93. Temido-Ferreira M, Ferreira DG, Batalha VL, Marques-Morgado I, Coelho JE, Pereira P, et al. Age-related shift in LTD is dependent on neuronal adenosine A2A receptors interplay with mGluR5 and NMDA receptors. Mol Psychiatry. 2018. https://doi. org/10.1038/s41380-018-0110-9. 